\title{
PREVALENCE AND RISK FACTORS FOR HUMAN TOXOPLASMOSIS IN A RURAL COMMUNITY
}

\section{MARQUES JM (1), DA SILVA DV (2), CORREIA NAB (3), VELÁSQUEZ LG (3), DA SILVA RC (4), LANGONI H (4), DA SILVA AV (5)}

(1) Masters Program in Animal Science, Paranaense University, UNIPAR, Umuarama, Paraná State, Brazil; (2) Undergraduate Nursing Program, Paranaense University, UNIPAR, Umuarama, Paraná State, Brazil; (3) Department of Pharmacy, Paranaense University, UNIPAR, Umuarama, Paraná State, Brazil; (4) Zoonosis Research Center, NUPEZO, Veterinary Medicine and Animal Husbandry School, São Paulo State University, UNESP, Botucatu, São Paulo State, Brazil; (5) Department of Animal Science, Paranaense University, UNIPAR, Umuarama, Paraná State, Brazil.

ABSTRACT: Toxoplasma gondii infection may lead to important pathological questions, especially in rural areas, where several sources of infection exist. Therefore, it is important to determine risk factors in order to establish adequate prophylactic measures. The present study aimed to assess the prevalence and risk factors involved in human toxoplasmosis infection in a rural community, in Eldorado, Mato Grosso do Sul State, Brazil. This community was composed of 185 farms - with 671 inhabitants - from which 20 were randomly chosen. In these farms, blood samples were collected from rural workers, who also answered a risk factor questionnaire. Serum samples were analyzed by means of direct agglutination test for the detection of anti-Toxoplasma gondii antibodies. From 73 samples collected, $79.45 \%$ were positive. None of the studied variables was significantly associated with the prevalence of the infection. However, among the individuals who reported eyesight impairments, $94.4 \%$ had anti-T. gondii antibodies, compared with $74.0 \%$ who did not report eyesight changes ( $p=0.0594)$. Moreover, most individuals in the study (68.20\%) were older than 18 years and presented $84.44 \%$ positivity, compared with $66.67 \%$ of positive individuals younger than 18 years old. We were able to conclude that a high prevalence of antibodies did not imply significant associations with the risk factors studied.

KEY WORDS: Toxoplasma gondii, prevalence, risk factors, rural community.

CONFLICTS OF INTEREST: There is no conflict.

FINANCIAL SOURCE: Paranaense University.

\section{CORRESPONDENCE TO}

ARISTEU VIEIRA DA SILVA, Departamento de Ciência Animal, Universidade Paranaense, Praça Mascarenhas de Moraes, s/n, Umuarama, PR, 87.502-210, Brasil. Phone: +55 443621 2885. Email: aristeu@unipar.br. 


\section{INTRODUCTION}

Toxoplasma gondii (Nicolle \& Manceaux, 1909) is classified in the phylum Apicomplexa, with near relatives in the Sarcocystidae family, particularly the following genera: Sarcocystis, Frenkelia, Hammondia and Neospora. Members of these genera have life cycles that alternate between intermediate hosts, in which asexual phases occur, and definitive hosts, in which sexual phases manifest. In intermediate hosts, generally herbivores or omnivores, one or more proliferative cycles arise in different tissues, leading to cyst production. In definitive hosts, usually carnivores, the sexual phase results in oocyst production in the intestines. Sporogony commonly develops within the definitive host, leading to the production of isospora-like oocysts that contain two sporocysts, with four sporozoites each (23).

The life cycle of $T$. gondii is facultatively heteroxenous: felids are definitive hosts, whereas probably all homoeothermic animals may be intermediate ones. Toxoplasmosis is one of the most common parasitic zoonosis and also causes significant economic losses to animal breeding industry. Humans and other animals may get infected by any of the three life-cycle forms of the protozoan:

- oocysts, eliminated in felid feces, can be ingested - they become infective from one to five days after sporulation;

- cysts, present tissues of intermediate hosts, may also be ingested;

- tachyzoites can be transmitted via uterine route, throuhg the placenta.

T. gondii may also be transmitted by blood products, organ transplants or by the ingestion of tachyzoites in unpasteurized goat milk (22).

In postnatal life, most human infections manifest after the ingestion of sporulated oocysts, found in the environment, or by the ingestion of tissue cysts, from raw or undercooked meat of intermediate hosts. However, the most important epidemiological route is yet to be determined and the main sources of $T$. gondii infection are diverse among human populations with different cultural and feeding habits (22).

Although the importance of livestock in toxoplasmosis transmission to humans remains unclear, pork represents the most important source of infection in several countries (7). On the other hand, there is an ever-growing interest in the study of the infection in poultry - mainly in extensively bred animals - caused by oocysts from contaminated soil (8). 
Nevertheless, the close contact between humans and pets, mainly dogs and cats, may lead to situations in which shared sources of infection can be evidenced, resulting in human infection (12). In the rural environment, risk factors may get superposed, contributing to high infection rates in humans, as reported in the literature $(4,6,11,12,14)$.

The present study aimed to assess the prevalence and risk factors related to Toxoplasma infection in individuals from a rural community in Eldorado, Mato Grosso do Sul State, Brazil.

\section{MATERIAL AND METHODS}

\section{Site of Collection and Sampling Plan}

Eldorado is a city of 11,934 inhabitants (2) located in southern Mato Grosso do Sul, about $470 \mathrm{~km}$ from the state capital, Campo Grande. The local economy is based on agriculture, mainly beef and dairy cattle breeding, as well as watermelon, soy, corn and cassava crops.

Blood samples were collected from members of a rural community, in Eldorado

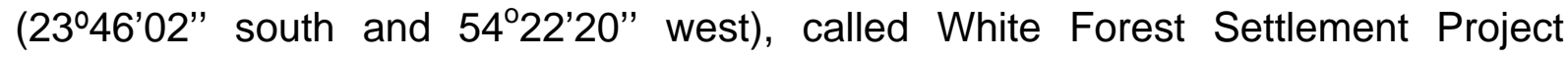
(Projeto de Assentamento Floresta Branca). The settlement was formed in January 1998. Eighty-six families (47\% of the total) came from Our Lady of Aparecida Camp (Acampamento Nossa Senhora Aparecida), in the city of Paranhos, in the BrazilParaguay border. Working conditions were irregular and these persons came back to Brazil seeking for a better quality of life. This encampment was coordinated by the Landless Workers' Movement (Movimento dos Trabalhadores Rurais Sem Terra) and by the Pastoral Land Commission (Pastoral da Terra). Other 86 families (47\%), organized by the Federation of Agricultural Workers (Federação dos Trabalhadores na Agricultura), were dislodged from the cities of Taquarussu and Bataiporã, MS, where they used to rent land lots. Finally, 13 families (6\%) were constituted by the remaining workers from a disappropriated farm.

Thus, White Forest Settlement Project consisted of 185 farms with 671 inhabitants, about 3.67 inhabitants per farm (median =4); minimum of one and maximum of nine individuals, according to the census carried out by the Institute of Agrarian Development, Technical Assistance and Rural Extension (Instituto de Desenvolvimento Agrário, Assistência Técnica e Extensão Rural) from the state of Mato Grosso do Sul. 
Blood samples were collected from all the individuals of the 20 farms randomly chosen. Blood collection of and questionnaire application were carried out only after persons received the necessary explanation about the investigation, its objectives and methods, and signed a consent form, for them and for those under their responsibility. The research project was approved by the Human Research Ethics Committee of the Paranaense University (Comitê de Ética em Pesquisa Envolvendo Seres Humanos da Universidade Paranaense), register number 10067.

\section{Collection of Samples}

Blood samples were collected by means of a puncture in the cephalic vein. Sera were obtained by centrifugation and stored at $-20^{\circ} \mathrm{C}$ until their analysis by serology for detection of anti-Toxoplasma gondii antibodies.

\section{Serological Examination}

Serum samples were analyzed through modified agglutination test (MAT) for detection of anti- $T$. gondii antibodies employing formalin-fixed antigens (5). Sera were initially screened at a 1:25 dilution, and then two-fold serial dilutions were used in order to determine antibody titers in positive samples for the screening process.

\section{Questionnaire}

In addition to blood collection, information related to the characterization of the individuals, their feeding habits and contact with animals were also gathered with a structured questionnaire, developed based on the literature $(1,15-17,21,25)$.

\section{Data Analysis}

Univariate analysis was carried out using the general prevalence of anti-T. gondii antibodies given by MAT results associated with data collected in questionnaires, in chi-square and Fischer's exact tests. Significance level was set at 5\% (24). 


\section{RESULTS AND DISCUSSION}

From the 73 samples collected, 58 (79.45\%; C195\%: 68.78-87.11) were positive for anti-T. gondii antibodies in MAT. After titration, 75.86\% (CI95\%: 63.40-85.01) of the samples presented titers greater than 400 , with at least one positive individual per farm.

The evaluation of the minimum number of samples - using $79.45 \%$ as the proportion and a population of 671 individuals - showed that 51 samples would provide reproducible results for the whole human population of the settlement.

Cavalcante et al. (4), using the modified direct agglutination test in the study of 266 persons from 71 farms in the state of Rondônia, found 73.3\% (CI95\%: 67.69-78.26) positive individuals. This result was similar to the one found in the present study, including antibody titers greater than 400 in $66.67 \%$ of the evaluated samples (CI95\%: 59.77-72.90).

The comparison with the results of indirect fluorescent antibody test (IFAt) by Cavalcante et al. (4) revealed high similarity with MAT. Given that, MAT may be a good option for toxoplasmosis diagnosis, since IFAT shows results analogous to those of the Sabin-Feldman reaction, considered the standard test for the diagnosis of human toxoplasmosis (9).

None of the variables was significantly associated with the prevalence of Toxoplasma infection according to Table 1. However, among the individuals that had reported eyesight impairment, 90.0\% (C195\%: 69.62-96.95) presented anti-T. gondii antibodies, compared with 75.5\% (C195\%: 62.36-85.04) who did not report any eyesight change ( $p=0.1472$ ). Garcia et al. (10) found 77\% (CI95\%: 66.62-85.32) seroreactors in 75 individuals that had manifested eyesight problems compared with $63 \%$ (C195\%: 56.90-68.38) in seronegative individuals. 
J. M. Marques et al. PREVALENCE AND RISK FACTORS FOR HUMAN TOXOPLASMOSIS IN A RURAL COMMUNITY. J. Venom. Anim. Toxins incl. Trop. Dis., 2008, 14, 4, p. 678

Table 1. Analysis of the association among studied variables and the presence of anti-Toxoplasma gondii antibodies in humans from a rural population, in Eldorado, Mato Grosso do Sul State, Brazil, 2007

\begin{tabular}{|c|c|c|c|c|}
\hline \multirow{2}{*}{$\begin{array}{ll} & \text { Test } \\
\text { Variable } & \\
\end{array}$} & \multicolumn{4}{|c|}{ Modified agglutination test (MAT) } \\
\hline & Negative & Positve & Total & p \\
\hline \multicolumn{5}{|l|}{ Sex } \\
\hline Female & $7(22.6 \%)$ & $24(77.4 \%)$ & $31(43.7 \%)$ & \multirow{2}{*}{0.7916} \\
\hline Male & $8(20.0 \%)$ & $32(80.0 \%)$ & $40(56.3 \%)$ & \\
\hline \multicolumn{5}{|l|}{ Visual impairment } \\
\hline No & $13(24.5 \%$ & $40(75.5 \%)$ & $53(72.6 \%)$ & \multirow{2}{*}{0.1472} \\
\hline Yes & $2(10.0 \%)$ & $18(90.0 \%)$ & $20(27.4 \%)$ & \\
\hline \multicolumn{5}{|l|}{ Headache } \\
\hline No & $12(21.4 \%)$ & $44(78.6 \%)$ & $56(76.7 \%)$ & \multirow{2}{*}{0.5168} \\
\hline Yes & $3(17.6 \%)$ & $14(82.4 \%)$ & $17(23.3 \%)$ & \\
\hline \multicolumn{5}{|l|}{ Meat consumption } \\
\hline Cattle & $15(20.5 \%)$ & $58(79.5 \%)$ & 73 & \multirow{6}{*}{0.9892} \\
\hline Goat & $15(21.1 \%)$ & $56(78.9 \%)$ & 71 & \\
\hline Hunted meat & $10(21.7 \%)$ & $36(78.3 \%)$ & 46 & \\
\hline Sheep & $0(0.0 \%)$ & $2(100.0 \%)$ & 2 & \\
\hline Poultry & $15(20.5 \%)$ & $58(79.5 \%)$ & 73 & \\
\hline Pork & $15(21.4 \%)$ & $55(78.6 \%)$ & 70 & \\
\hline \multicolumn{5}{|c|}{ Raw tripe and offal consumption } \\
\hline No & $1(33.3 \%)$ & $2(66.7 \%)$ & $3(4.1 \%)$ & \multirow{2}{*}{0.5038} \\
\hline Yes & $14(20.0 \%)$ & $56(80.0 \%)$ & $70(95.9 \%)$ & \\
\hline \multicolumn{5}{|l|}{ Cheese consumption } \\
\hline No & $0(0.0 \%)$ & $1(100 \%)$ & $1(1.4 \%)$ & \multirow{2}{*}{0.7945} \\
\hline Yes & $15(20.8 \%)$ & $57(79.2 \%)$ & $72(98.6 \%)$ & \\
\hline Boil water & & & & \\
\hline No & $15(20.8 \%)$ & $57(79.2 \%)$ & $72(98.6 \%)$ & \\
\hline Yes & $0(0.0 \%)$ & $1(100 \%)$ & $1(1.4 \%)$ & 0.7945 \\
\hline Filtered water & & & & \\
\hline No & $11(18.0 \%)$ & $50(82.0 \%)$ & $61(83.6 \%$ & \\
\hline Yes & $4(33.3 \%$ & $8(66.7 \%)$ & $12(16.4 \%)$ & 0.2041 \\
\hline Gardening practice & & & & \\
\hline No & $5(19.2 \%)$ & $21(80.8 \%)$ & $26(35.6 \%)$ & \\
\hline Yes & $10(21.3 \%)$ & $37(78.7 \%)$ & $47(64.4 \%)$ & 0.5447 \\
\hline Have a vegetable garden & & & & \\
\hline No & $2(22.2 \%)$ & $7(77.8 \%)$ & $9(12.3 \%)$ & \\
\hline Yes & $13(20.3 \%)$ & $51(79.7 \%)$ & $64(87.7 \%)$ & 0.5941 \\
\hline Agriculture practice & & & & \\
\hline No & $2(16.7 \%)$ & $10(83.3 \%)$ & $12(16.4 \%)$ & \\
\hline Yes & $13(21.3 \%)$ & $48(78.7 \%)$ & $61(83.6 \%)$ & 0.5322 \\
\hline Soil contact & & & & \\
\hline No & $10(16.1 \%)$ & $52(83.9 \%)$ & $62(87.3 \%)$ & \\
\hline Yes & $4(44.4 \%)$ & $5(55.6 \%)$ & $9(12.7 \%)$ & 0.0681 \\
\hline Raw meat contact & & & & \\
\hline No & $4(33.3 \%)$ & $8(66.7 \%)$ & $12(16.4 \%)$ & \\
\hline Yes & $11(18.0 \%)$ & $50(82.7 \%)$ & $61(83.6 \%)$ & 0.2041 \\
\hline Hand-washing after conta & meat & & & \\
\hline No & $4(26.7 \%)$ & $11(73.3 \%)$ & $15(20.5 \%)$ & \\
\hline Yes & $11(19.0 \%)$ & $47(81.0 \%)$ & $58(79.5 \%)$ & 0.3680 \\
\hline Have cats & & & & \\
\hline No & $6(25.0 \%$ & $18(75.0 \%)$ & $24(32.9 \%)$ & \\
\hline Yes & $9(18.4 \%)$ & $40(81.6 \%)$ & $49(67.1 \%)$ & 0.3664 \\
\hline Have or had cat with kitte & & & & \\
\hline No & $6(24.0 \%)$ & $19(76.0 \%)$ & $25(20.5 \%)$ & \\
\hline Yes & $9(18.8 \%)$ & $39(81.3 \%)$ & $48(65.8 \%)$ & 0.4057 \\
\hline Keep cats inside home & & & & \\
\hline No & $7(28.0 \%)$ & $18(72.0 \%)$ & $25(34.7 \%)$ & \\
\hline Yes & $8(17.0 \%)$ & $39(83.0 \%)$ & $47(65.3 \%)$ & 0.2131 \\
\hline Feed cats with raw meat & & & & \\
\hline No & $6(27.3 \%)$ & $16(72.7 \%)$ & $22(30.1 \%)$ & \\
\hline Yes & $9(17.6 \%)$ & $42(82.4 \%)$ & $51(69.9 \%)$ & 0.2635 \\
\hline Cat feces exposition & & & & \\
\hline No & $13(18.8 \%)$ & $56(81.2 \%)$ & 69 (94.5\%) & \\
\hline Yes & $2(50.0 \%)$ & $2(50.0 \%$ & $4(5.5 \%)$ & 0.1849 \\
\hline Feed animals & & & & \\
\hline No & $4(26.7 \%)$ & $11(73.3 \%)$ & $15(20.5 \%)$ & \\
\hline Yes & $11(19.0 \%)$ & $47(81.0 \%)$ & $58(79.5 \%)$ & 0.3680 \\
\hline
\end{tabular}


Many factors may present association with Toxoplasma infection in humans and the high prevalence observed in the present study did not point at any particular aspect. Garcia and Navarro (11) did not identify risk factors in a rural population where $71.3 \%$ of the individuals were positive, whereas Camargo et al. (3) registered that contact with cats, poultry and pigs were factors associated with the infection in the metropolitan area of Belo Horizonte, Minas Gerais State, Brazil. Finally, BahiaOliveira et al. (1), in Campos dos Goytacazes, Brazilian state of Rio de Janeiro, considered that the consumption of undercooked meat and unfiltered water were risk factors for Toxoplasma infection.

An important aspect in the infection characterization, although not significantly associated with it, was that $70.83 \%$ of the persons were more than 18 years old. In this age group, $84.31 \%$ of the members showed positive results (C195\%: 71.9291.77) while 66.67\% (CI95\%: 45.13-82.80) of positive individuals were less than 18 years old. These results were similar to those reported by Garcia et al. (10), who found $43.82 \%$ (CI95\%: 33.96-54.20) of seroreactors in individuals up to 15 years old and 73.44\% (CI95\%: 67.70-78.47) positivity in individuals aged 16 years or older. They were also similar to the findings by Cavalcante et al. (4), who reported $56.70 \%$ (CI95\%: 46.75-66.13) positivity in individuals up to 19 years old and 82.84\% (CI95\%: 76.43-87.76) in persons aged 20 years or more.

Prevalence of anti-T. gondii antibodies in humans was compared with positive DA rates found in the animal population of the settlement - serum dilution was 1:25 with the following results: $79.45 \%, 60.87 \%, 57.14 \%, 47.61 \%, 22.89 \%, 14.71 \%$ and $5.15 \%$, respectively, for humans (in this study), horses (7), cats (15), dogs (15), poultry (18), pigs (19) and cattle (13). The rate of positive results was significantly lower in dogs, pigs, poultry and cattle, compared with humans.

Antibody rates recorded for different species may propose that there were different risk factors associated with the prevalence of Toxoplasma infection in the community. The high prevalence among humans, horses and cats could be justified by the exposure of humans and horses to places highly contaminated with cat feces, or by increased chance of infection determined by the age of these individuals. Therefore, age may also be involved as a factor in the lower antibody rates observed in dogs, pigs, poultry and cattle, due to the fact that most of these animals were young.

Garcia et al. (10) found a similarity between serum antibody titers in humans and those found in dogs and cats. These authors deliberated that a common source of 
infection may be implied because both species are carnivores, and feeding habits could be responsible for both infections, while cats would have an indirect role, contaminating the environment with oocysts.

Konishi and Takahashi (17), in a study accomplished in a Japanese rural community, collected 3,606 blood samples from farmers, and reported that gender, age and consumption of raw meat were factors associated with seropositive results.

Suárez-Hernández et al. (20), studying 548 samples from Cuban children by IgGIFAT, observed that the main risk factor was the child origin. Prevalence of positivity in children from rural communities was $57 \%$, whereas in those of urban groups was $27 \%$.

In Central Valley, Costa Rica, Zapata et al. (26) serologically examined 400 volunteers ranging from 20 to 40 years old by ELISA-IgG. General prevalence was $58 \%$, with $61.5 \%$ positivity for men and $55 \%$ for women ( $p>0.05$ ); $62.7 \%$ of the individuals from rural areas were positive compared with $56.4 \%$ individuals from urban areas $(p>0.05)$. Age (between 36 and 40 years) and low socioeconomic level were the only indicators associated with positive serological results.

Jones et al. (15) investigated factors connected with toxoplasmosis prevalence among 500 children, from three to ten years old, in a rural area of Guatemala. Employing ELISA-IgG, in 1999 they determined an infection rate of $12.4 \%$ and in 2003 , the rate was $37.8 \%$. In the first period, increased age was the only predictor of infection risk, whereas in 2003, consumption of goat milk, well water and presence of cat feces in residences were the associated risk factors.

In Ireland, Taylor et al. (21) analyzed the rate of anti- $T$. gondii antibodies in 1,276 children - by latex agglutination - and the risk factors associated with positive results. The prevalence was $12.8 \%$, with no association with the child gender or with being a cat owner. Positive results increased with age and were also connected with rural origin (16.6\% positive). Being a owner of a pregnant dog or not treating pet dogs against helminth infection in the previous year were also situations that revealed association with positive results. However, latter factors were considered to be either the evidence of an alternative route of infection (less probable) or indicators of the lack of hygiene regarding household pets.

The Erechim region, in the Brazilian state of Rio Grande do Sul, is worldwide known for the highest prevalence of ocular toxoplasmosis. Jones et al. (16) observed components related to the occurrence of acute toxoplasmosis in this region; they 
interviewed 131 patients who had shown serological markers of acute infection - $\mathrm{i}$. e., positive results for IgG and IgM antibodies - and compared these results with those from seronegative patients. Of the several factors displayed by the univariate analysis, only garden work (odds ratio $=2.35$ ) and eating lamb (odds ratio $=2.06$ ) were significantly associated with the disease, when the same data were evaluated by logistic regression (multivariate analysis).

A review of the literature shows that different factors are associated with Toxoplasma gondii infection, especially the region, period and population under investigation. It is evident that local studies are necessary to determine risk factors associated with $T$. gondii infection in a given population - with its own characteristics of interaction between animal populations and the environment, and peculiar feeding and hygienic habits - and to create specific strategies to prevent the infection.

\section{CONCLUSIONS}

In the present study, no association between epidemiological factors and risk of infection were drawn. However, human populations may be at a constant risk due to feeding habits and contact with infected animals and soil. Given that, prophylactic measures should be applied to risk groups, i. e., pregnant non-infected women and immunocompromised individuals, due to the risk of ocular diseases and/or reacutization cases. 


\section{REFERENCES}

1 BAHIA-OLIVEIRA LM., JONES JL., AZEVEDO-SILVA J., ALVES CC., ORÉFICE F., ADDISS DG. Highly endemic, waterborne toxoplasmosis in North Rio de Janeiro state, Brazil. Emerg. Infec. Dis., 2003, 9, 55-62.

2 BRASIL. Instituto Brasileiro de Geografia e Estatística. Available from: <http://www.ibge.gov.br/home/>. Accessed in: Nov. 12, 2008.

3 CAMARGO MCV., ANTUNES CM., CHIARI CA. Epidemiologia da infecção por Toxoplasma gondii no município de Ribeirão das Neves, MG: I - Importância dos animais domésticos como fonte de infecção do T. gondii para o homem. Rev. Soc. Bras. Med. Trop., 1995, 28, 211-4.

4 CAVAlCANTE GT., AGUIAR DM., CAMARGO LMA., LABRUNA M., DE ANDRADE H., MEIRELES L., DUBEY J., THULLIEZ P., DIAS R., GENNARI S. Seroprevalence of Toxoplasma gondii antibodies in humans from rural western Amazon, Brazil. J. Parasitol., 2006, 92, 647-9.

5 DA SILVA AV., CUTOLO AA., LANGONI H. Comparação da reação de imunofluorescência indireta e do método de aglutinação direta na detecção de anticorpos anti-toxoplasma em soros de ovinos, caprinos, caninos e felinos. Arq. Inst. Biol., 2002, 69, 7-11.

6 DALMOLIN A., GUERRA IMP., MARQUES JM., SILVA RC., LANGONI H., DA SILVA AV. Toxoplasmose em uma comunidade rural de Eldorado, MS. Prevalência de anticorpos em eqüinos In: VI ENCONTRO DE INICIAÇÃO CIENTÍFICA, VI FÓRUM DE PESQUISA DA UNIPAR, II ENCONTRO CIENTÍFICO DO MESTRADO EM CIÊNCIA ANIMAL, 2007, Umuarama. Anais... Umuarama: CEDIC, 2007, 1, 39.

7 DUBEY JP. Toxoplasmosis. J. Am. Vet. Med. Assoc. 1994, 205, 1593-8.

8 DUBEY J., VIANNA MCB., SOUSA S., CANADA N., MEIRELES S., CORREIA DA COSTA J., MARCET P., LEHMANN T., DARDÉ M., THULLIEZ P. Characterization of Toxoplasma gondii isolates in free-range chickens from Portugal. J. Parasitol., 2006, 92, 184-6.

9 DUBEY JP., BEATTIE CP. Toxoplasmosis of animals and man. Boca Raton, FL: CRC Press, 1988. 37-8p.

10 GARCIA JL., NAVARRO IT., OGAWA L., DE OLIVEIRA RC., KOBILKA E. Soroprevalência, epidemiologia e avaliação ocular da toxoplasmose humana na zona rural de Jaguapitã (Paraná), Brasil. Rev. Panam. Salud Publ., 1999, 6, 157-63. 
11 GARCIA JL., NAVARRO IT. Levantamento soroepidemiológico da toxoplasmose em moradores da zona rural do município de Guaraci - Paraná - Brasil. Semina, $1995,16,63-7$.

12 GERMANO PML., ERBOLATO EB., ISHIZUKA MM. Estudo sorológico da toxoplasmose canina pela prova de imunofluorescência indireta na cidade de Campinas. Rev. Fac. Med. Vet. Zootec. Univ. São Paulo, 1981, 22, 53-8.

13 GUERRA IMP., MARQUES JM., DALMOLIN A., SILVA RC., LANGONI H., DA SILVA AV. Toxoplasmose em uma comunidade rural: prevalência de anticorpos em bovinos In: VI ENCONTRO DE INICIAÇÃO CIENTÍFICA, VI FÓRUM DE PESQUISA DA UNIPAR, II ENCONTRO CIENTÍFICO DO MESTRADO EM CIÊNCIA ANIMAL, 2007, Umuarama. Anais... Umuarama: CEDIC, 2007, 1, 41.

14 ISBRESCHT FB., MARQUES JM., SILVA RC., LANGONI H., DA SILVA AV. Toxoplasmose em uma comunidade rural. Prevalência de anticorpos em cães e gatos In: VI ENCONTRO DE INICIAÇÃO CIENTÍFICA, VI FÓRUM DE PESQUISA DA UNIPAR, II ENCONTRO CIENTÍFICO DO MESTRADO EM CIÊNCIA ANIMAL, 2007, Umuarama. Anais... Umuarama: CEDIC, 2007, 1, 40-1.

15 JONES JL. LOPES B., MURY MA., WILSON M., KLEIN R., LUBY S., MAGUIRE $\mathrm{JH}$. Toxoplasma gondii infection in rural Guatemalan children. Am. J. Trop. Med. Hyg., 2005, 72, 295-300.

16 JONES JL. MUCCIOLI C., BELFORT JUNIOR R., HOLLAND GN., ROBERTS JM., SILVEIRA C. Recently acquired Toxoplasma gondi infection, Brazil. Emerg. Infect. Dis., 2006, 12, 582-7.

17 KONISHI E., TAKAHASHI J. Some epidemiological aspects of Toxoplasma infections in a population of farmers in Japan. Int. J. Epidemiol., 1987, 16, 277-81.

18 LUCAS TM., MARQUES JM., ZAMPROGNA TO., ROSA RC., GALLI S., SILVA RC., LANGONI H., DA SILVA AV. Toxoplasmose em uma comunidade rural: freqüência de anticorpos em galinhas. In: VI ENCONTRO DE INICIAÇÃO CIENTÍFICA, VI FÓRUM DE PESQUISA DA UNIPAR, II ENCONTRO CIENTÍFICO DO MESTRADO EM CIÊNCIA ANIMAL, 2007, Umuarama. Anais... Umuarama: CEDIC, 2007, 1, 133-4. 
19 ROSA RC., MARQUES JM., LUCAS TM., ZAMPROGNA TO., SILVA RC., LANGONI H., Da SILVA AV. Toxoplasmose em uma comunidade rural. Detecção de anticorpos anti-Toxoplasma gondii em suínos e ovinos In: VI ENCONTRO DE INICIAÇÃO CIENTÍFICA, VI FÓRUM DE PESQUISA DA UNIPAR, II ENCONTRO CIENTÍFICO DO MESTRADO EM CIÊNCIA ANIMAL, 2007, Umuarama, 2007. Anais... Umuarama: CEDIC, 2007, 1, 40.

20 SUÁREZ-HERNÁNDEZ M., GONZÁLEZ-FERNÁNDEZ A., GARDÓN-QUIROLA BY., MARTINEZ-SÁNCHEZ R. Infección y enfermedad por Toxoplasma gondii en animales y humanos en 23 años de observación en la provincia de Ciego de Ávila, Cuba. Rev. Biomed., 2005, 16, 21-7.

21 TAYLOR MRH., LENNON B., HOLLAND CV., CAFFERKEY M. Communit study of Toxoplasma antibodies in urban and rural schoolchildren aged 4 to 18 years. Arch. Dis. Child., 1997, 77, 406-9.

22 TENTER AM. Current knowledge on the epidemiology of infections with Toxoplasma. Tokai J. Exp. Clin. Med., 1999, 23, 391.

23 TENTER AM., JOHNSON AM. Phylogeny of the tissue cyst-forming coccidia. Adv. Parasitol., 1997, 39, 69-139.

24 TRIOLA MF. Introdução à estatística. Rio de Janeiro: LTC, 1999. 476p.

25 WEIGEL RM., DUBEY JP., DYER D., SIEGEL AM. Risk factors for infection with Toxoplasma gondii for residents and workers on swine farms in Illinois. Am. J. Trop. Med. Hyg., 1999, 60, 793-8.

26 ZAPATA M., REYES L., HOLST I. Disminución en la prevalencia de anticuerpos contra Toxoplasma gondii en adultos del valle central de Costa Rica. Parasitol. Latinoam., 2005, 60, 32-7. 